\title{
安定地点を考慮した土地利用遷移予測モデル
}

\author{
大佛 俊泰、倍田 賢一
}

\section{Land-use Forecasts Considering the Existence of Steady-state Places}

\author{
Toshihiro OSARAGI and Kenichi MASUDA
}

\begin{abstract}
Many studies on land-use transition have been carried out using a Markov chain model. Its transition probability matrix on land-use is usually estimated from current or historical data in the study area. In this process it is assumed that every place in the area is changeable following to the Markov chain process. However, there are some places whose land-use is in steady state. In this paper we propose a method for estimating the transition probability considering the existence of such steady places. Also effectiveness of this method is examined by numerical examples.
\end{abstract}

Keywords: 土地利用遷移予測(Land-use forecast)、マルコフ連鎖 (Markov chain)、土地利用遷移行列 (Transition matrix of land-use)、メッシュデータ(Lattice data)

\section{1.はじめに}

都市・地域計画の分野において、土地利用変化の 予測や土地利用転換構造の分析は、今後の計画案策 定の際の基礎資料となるだけでなく、過去の土地利 用政策の評価を行う際にも重要である。そのため、 近年におけるメッシュデータの整備を背景として、 土地利用の遷移構造をいかに分析するか、という点 に関して様々な手法の提案がなされている。例えば 金ほか(1991)は土地利用遷移確率行列を用いた土地 利用用途の転移分析を試みている。また石坂 (1992a、1992b)はこの研究を発展させ、遷移確率行 列の固有值・固有ベクトルを用いた土地利用転換過 程の構造を分析する手法を提案している。さらに青 木ほか(1994)は遷移確率行列を用いた土地利用分析 において生じる予測誤差の評価方法を提案してい る。

これら従来の研究では、対象とする全ての地点が 確率過程に従って変化することを仮定して、2 時点

大佛： $\overline{152}$ 東京都目黒区大岡山2-12-1 Tel.03-5734-3162 東京工業大学大学院情報環境学専攻

Department of Mechanical and Environmental Informatics, Tokyo Institute of Technology, 2-12-1 Ookayama, Meguro-ku, Tokyo 152
の土地利用メッシュデータより遷移確率行列を推定 するという方法をとっていた。しかし現実には、商 業業務的土地利用に特化した駅前地区のように、他 の土地利用形態に変化することが少なく、ある土地 利用形態のまま安定的に存在し続ける地点もある。 つまり対象地域内には、分析しようとする時間範囲 内において確率的には変化しない安定した地点（以 下、「安定地点」と呼ぶ）も存在する可能性があ る。したがって、従来のモデルを安易に用いると、 安定地点においても、他の地点と同様の遷移確率に よって土地利用変化が生じてしまうことになり、土 地利用予測の際に誤った予測值を導く危険性があ る。

本研究では、安定地点の存在を考慮しながら従来 のマルコフ連鎖型モデルに改良を加え、新たな遷移 確率モデルを構築することを目的とする。まず、第 2 章では従来の遷移確率モデルにかわり、土地利用 の安定地点の存在を考慮した新しい遷移確率モデル を構筑し、第 3 章でモデルの推定方法を述べる。さ らに、第 4 章、第 5 章では現実デー夕を用いた数值 計算をもとに、従来のモデルとの比較分析を試み、 新しいモデの有効性を検証する。 


\section{2. 安定地点の存在を考慮した遷移確率モデル}

\section{1. 従来の遷移確率モデル（Pモデル）}

定常マルコフ連鎖を用いた従来のモデルでは、時 点 $t+1$ での土地利用 $i$ の面積 $x_{i}(t+1)$ は遷移確率 $p_{t y}$ を用 いて次のように記述していた。

$$
x_{i}(t+1)=\Sigma_{j} p_{i j} x_{j}(t)
$$

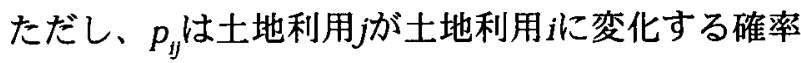
である。通常この $p_{i j}$ は、図 1 に示すように過去の 2 時点間 $(t=0 \sim 1)$ において土地利用がjからに変化した 対象地域内の全面積 $m_{i j}$ を用いて、次式で推定してい た。

$$
p_{i j}=\frac{m_{i j}}{\sum_{i} m_{i j}}
$$

すなわち、遷移確率 $p_{i j}$ は、対象地域内の全ての地点 が確率的に変化しているという仮定のもとで推定さ れている。本研究ではこの遷移確率モデルを、「P モデル」と呼ぶことにする。

\section{2. 安定地点を考慮した遷移確率モデル(Qモデル)}

対象とする地域内に、確率的には変化しない地点 （安定地点）が含まれる場合、前節で記述した遷移 確率 $p_{i j}$ は真の遷移構造を反映していない。つまり、

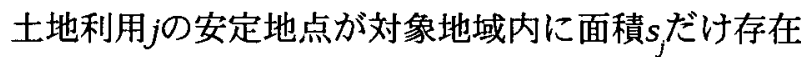
する場合には、図 2 に示すように、変化する地点の みを用いて遷移確率行列を推定するべきである。す なわち、土地利用遷移モデルは次のように記述する 必要がある。

$$
x_{i}(t+1)=s_{i}+\sum_{j} q_{i j}\left(x_{j}(t)-s_{j}\right)
$$

ここで、 $q_{i j}$ は安定地点の面積を除いた部分について の遷移確率である。このとき、このモデルの遷移確 率 $q_{i j}$ の推定值は次式で与えられる。

$$
\left\{\begin{array}{l}
q_{i j}=\frac{m_{i j}}{\sum_{i} m_{i j}-s_{j}} \quad(i \neq j) \\
q_{j j}=\frac{m_{j j}-s_{j}}{\sum_{i} m_{i j}-s_{j}}
\end{array}\right.
$$

安定地点の面積を考慮した土地利用遷移モデルを、 本研究では「Qモデル」と呼ぶ。

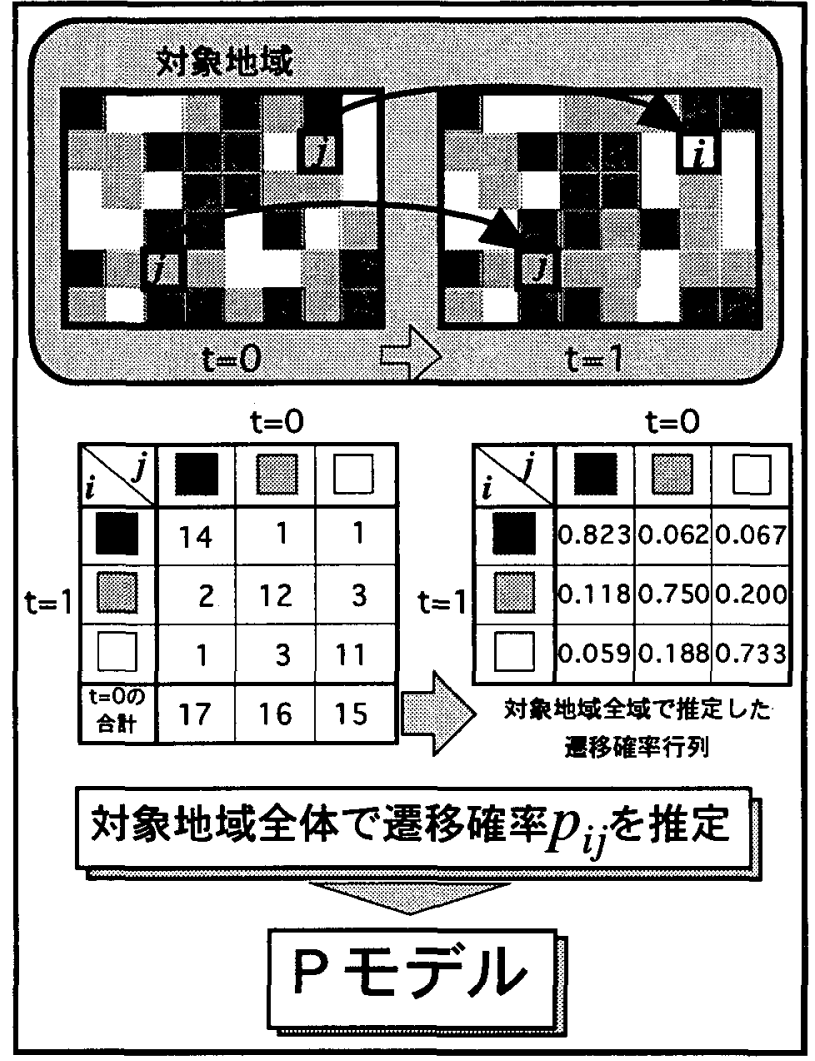

図 1 従来の遷移確率行列推定方法

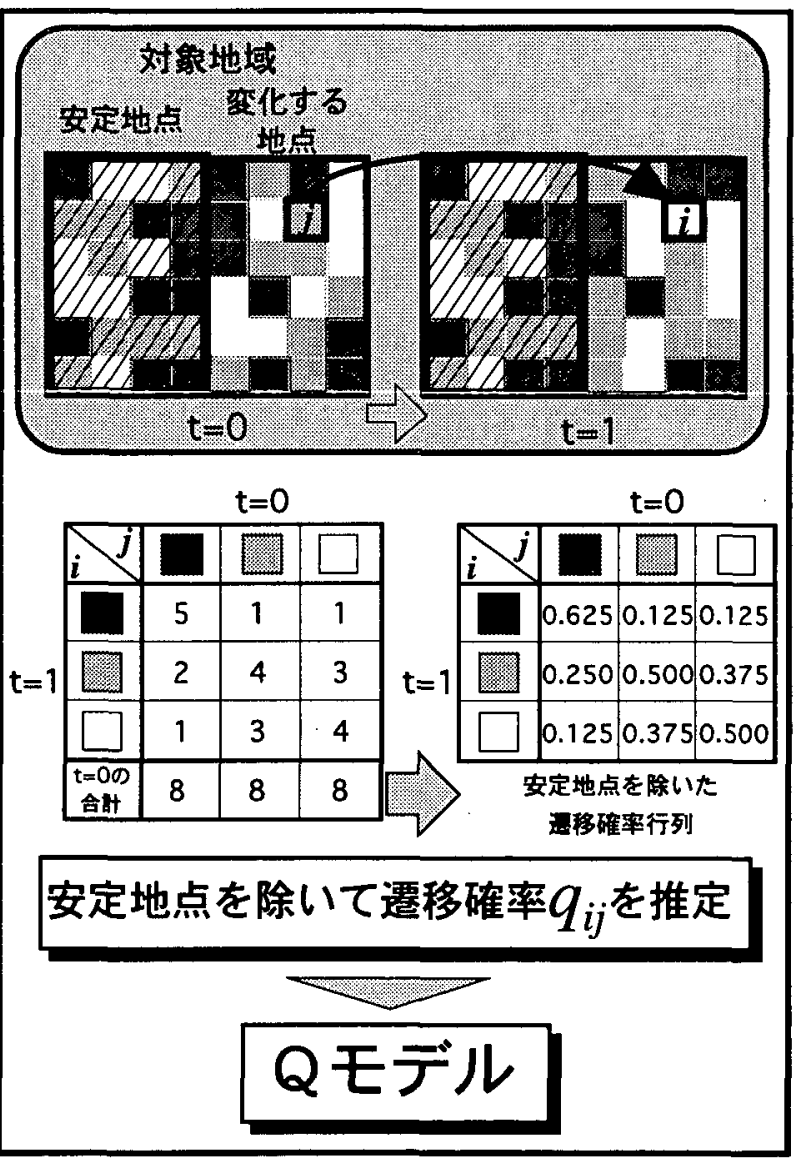

図 2 安定地点を考慮した遷移確率行列の推定方法 


\section{Qモデルの推定方法}

\section{1. パラメータの推定}

安定地点の面積 $s_{j}$ の、 $t=0$ における土地利用 $j$ の総 面積に対する割合を $a_{j}$ と表すと、次式を得る。

$$
a_{j}=\frac{s_{j}}{\sum_{i} m_{i j}}
$$

このとき、 $p_{i j}$ と $q_{i j}$ には次式の関係が存在する。

$$
\left\{\begin{aligned}
p_{i j} & =\frac{\sum_{i} m_{i j}-s_{j}}{\sum_{i} m_{i j}} \frac{m_{i j}}{\sum_{i} m_{i j}-s_{j}} \\
& =\left(1-a_{j}\right) q_{i j} \quad(i \neq j) \\
p_{j j} & =\frac{s_{j}}{\sum_{i} m_{i j}}+\frac{\sum_{i} m_{i j}-s_{j}}{\sum_{i} m_{i j}} \frac{m_{j j}-s_{j}}{\sum_{i} m_{i j}-s_{j}} \\
& =a_{j}+\left(1-a_{j}\right) q_{j j}
\end{aligned}\right.
$$

また、対象地域内から任意にある地点を抽出したと き、その土地利用 $j$ 時点 $t=022$ の間にまったく変化 しない確率を $r_{j}$ とすると、 $r_{j}$ は $a_{j}$ と $q_{i j}$ を用いて、次 のように表現することができる。

$$
r_{j}=a_{j}+\left(1-a_{j}\right) q_{j j}^{2}
$$

式(5)－(7)より $a_{j}$ を消去すると、

$$
\left\{\begin{array}{l}
q_{i j}=\frac{p_{i j}\left(1-q_{j j}^{2}\right)}{1-r_{j}} \quad(i \neq j) \\
q_{j j}=\frac{p_{j j}-r_{j}}{1-p_{j j}} .
\end{array}\right.
$$

が得られる。このとき土地利用に関する数值情報が 3 時点 $(t=0 、 1 、 2)$ で得られていれば、 $p_{i j^{\prime}} p_{i j^{\prime}} r_{j}$ 仗実 際のデータから推定可能であるので、Qモデルの遷 移確率 $q_{i j}$ は式(10)・(11)より推定できる。また式(9)よ り、土地利用 $j$ の安定地点の面積の割合 $a_{j}$ も推定可能 である（図 3）。

\section{2. パラメータの条件}

式(10)、(11)で推定されるQモデルのパラメータ は、以下に示す条件を満足する必要がある。

$$
\begin{aligned}
& 0<q_{j j}<1 \\
& 0 \leqq a_{j}<1
\end{aligned}
$$

式(12)・(13)を式(9)－(11)をもとに整理すると、

$$
\begin{aligned}
& 2 p_{j j}-1<r_{j}<p_{j j} \\
& p_{j j}{ }^{2} \leqq r_{j}
\end{aligned}
$$

が得られる。これらを满足する $p_{j j}$ と $r_{j}$ の関係を図 4 に 示す。式(9)-(11)から $a_{j} 、 q_{i j}$ の值は推定されるが、 デー夕数が少なく $p_{i j}, r_{j}$ が安定的に推定できない場合 には図4の範囲におさまらない可能性もある。その

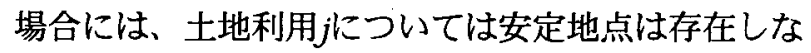

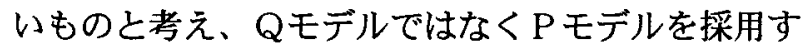
ればよい。さらに、 $t=0 \sim 1$ と $t=1 \sim 2$ の土地利用遷移 構造の間に大きな違いがある場合にも同様の問題が 生じるが、遷移構造の定常性が仮定できない状況下 では安易なモデルの適用は危険である。遷移構造が

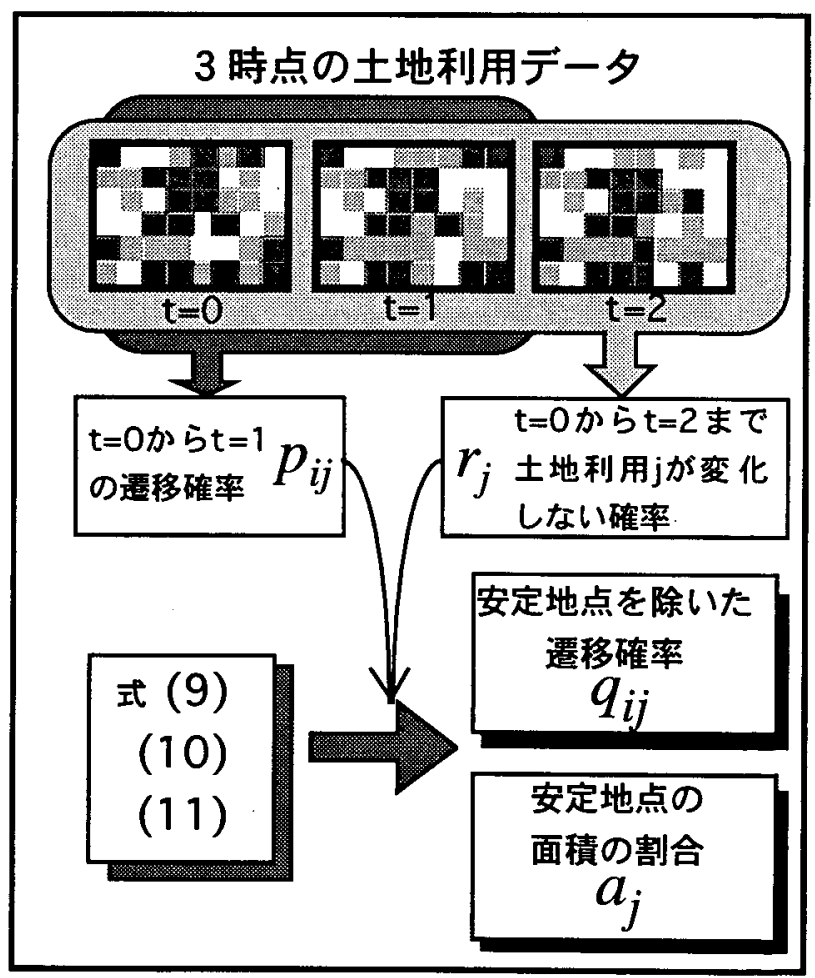

図 3 Qモデルのパラメータ推定

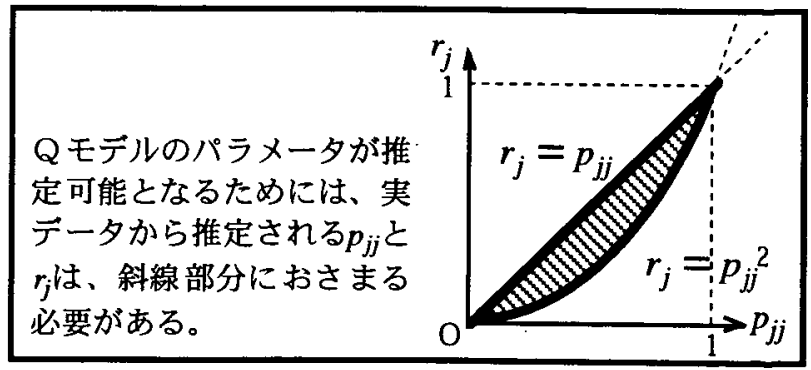

図4 パラメータの条件 
時間とともに変化する場合への対応は今後の検討課 題である。

\section{4. 実データを用いた安定地点の面積の推定}

ここでは、表 1 に示す現実のデータを用いて、Q モデルにより安定地点の面積の割合を推定し、安定 地点の存在を確認することを試みる。

まず、図 5 に示した分析対象地域（A）の全域の データを用いて、各土地利用項目別に安定地点の面 積の割合 $a_{j}$ を推定し、表 2 に示した。この結果、空 地については $a_{2}=0.337$ と低く、ほとんどの空地は確 率的に変化しやすく、安定地点は他の土地利用項目 と比較して少ないことがわかる。一方、住宅用地は $a_{3}=0.938$ と非常に高く、安定地点の割合は高い。商 業業務用地、公共用地はともに約0.86であり、住宅 用地の値には及ばないものの、高い割合で安定地点 が存在することがわかる。

以上の安定地点の割合は、都市空間内で必ずしも 一様ではない可能性がある。そこで、都心からの距 離によって安定地点の割合がどのように変化してい るかを確認するため、距離圏別に土地利用の安定面 積の推定を試みた（図 6)。商業業務用地に注目す ると、都心部に近づくほど $a_{4}$ の值は1.0に近づき、商 業業務用地は安定的に存在していることがわかる。 しかし、都心から遠ざかるにつれて安定地点の面積 は減少し、さらに遠い地点で再び上昇する。これ は、黄洪卢六宮、尺王子などの商業集積地域がこの 距離圏に含まれるためと推測される。一方、公共用 地については、都心からの距離によらず 8 割以上の 面積が安定的に存在している。住宅用地について は、郊外で安定地点の面積が多いものの、都心では 図 4 に示した条件は満足されず、 $a_{j}$ の值は推定不能 となった。住宅用地の遷移構造そのものが、分析対 象とした時点内で変化している可能性がある。空地 については、他の項目に比べ值は小さく、ほとんど の地点が確率的に変化しやすいことがあらわれてい る。特に、都心に近くなるほど值は小さく、都心寄 りの空地ほど確率的に変化しやすいことを示唆して いる。

以上の結果から、確率過程に従わない安定地点が

\section{表 1 土地利用データの概要}

\begin{tabular}{|c|c|c|}
\hline \multicolumn{3}{|c|}{$\begin{array}{r}\text { 使用データ : 国土地理院発行細密数値情報 } \\
\text { 土地利用データ } \\
\text { メッシュサイ } 1974.79 、 84] \\
\end{array}$} \\
\hline 番号 & $\begin{array}{c}\text { 本研究に } \\
\text { おける分類 }\end{array}$ & 細密数值情報の分類 \\
\hline 1 & 山林農地 & 山林荒地 田 畑 \\
\hline 2 & 空 地 & 造成中地 空地 \\
\hline 3. & 住宅用地 & $\begin{array}{l}\text { 一般低層住宅地 密集低層住宅地 } \\
\text { 中高層住宅地 }\end{array}$ \\
\hline 4 & 商業業務用地 & 商業業務用地 \\
\hline 5 & 公共用地 & 道路 公園 公共公益用地 \\
\hline & （分析対象外） & 工業用地 河川・湖沼等 その他 海 \\
\hline
\end{tabular}

注）本研究では細密数値情報の土地利用項目を上の表のよう に再分類した。ただし、「河川・湖沼等」、「海」、「その他」は 除外した。また、「業用地」については、パラメータを安定 的に推定できなかったので、今回の分析では除外した。

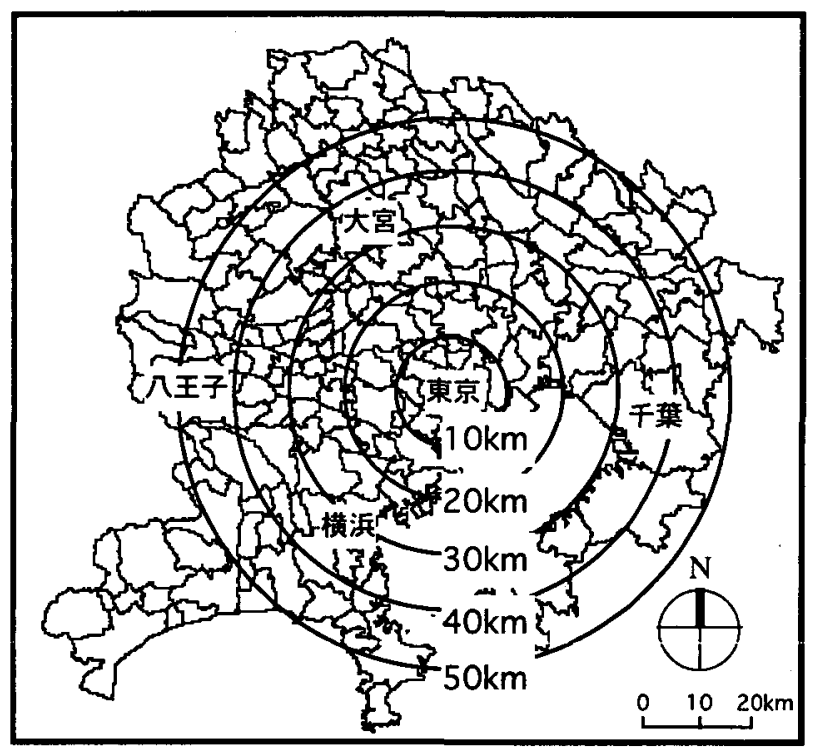

図 5 分析対象地域(A)

\section{表 2 首都圈全域での安定地点の割合}

\begin{tabular}{|c|c|c|c|c|c|}
\hline $\begin{array}{c}\text { 土地利用 } \\
\text { 碩目 }\end{array}$ & $\begin{array}{c}1 \\
\text { 山林農地 }\end{array}$ & $\begin{array}{c}2 \\
\text { 空地 }\end{array}$ & $\begin{array}{c}3 \\
\text { 住宅用地 }\end{array}$ & $\begin{array}{c}4 \\
\text { 商業業務 }\end{array}$ & $\begin{array}{c}5 \\
\text { 公共用地 }\end{array}$ \\
\hline $\begin{array}{c}\text { 安定地点 } \\
\text { の揢合 }\end{array}$ & 0.620 & 0.337 & 0.938 & 0.860 & 0.867 \\
\hline
\end{tabular}

多く存在することが確認でき、土地利用遷移予測の 際には、安定地点の存在を考慮する必要性が高いこ とが明らかとなった。

5.PモテルとQモデルの比較 
以下では、分析対象地域内に安定地点が存在する

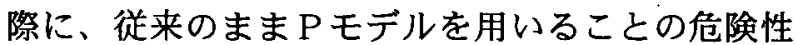
と、Qモデルを用いることの有効性を、二つのモデ ル比較を通して確認する。なお、ここでは真の土地 利用遷移を仮想的に作成することとした。作成方法 は、まず図 7 に示す対象地域（B）に、「確率的に変 化する地点」と「安定地点」を想定し、「確率的に変化 する地点」内の現実のデータ（1974年、1984年）を もとに真の遷移確率 $q^{*}{ }_{i j}$ （表 3）を作成した。そし て、1974年の土地利用の状態を $t=-1$ の状態とし、 $q^{*}$ を用いて $t=0 、 1 、 2 、 \cdots$ 状態の仮想データマップ を作成した。さらに、 $t=1$ を現時点とみなして、P モデルの遷移確率 $p_{i j}$ は $t=0 、 1 の 2$ 時点のデータから 推定し（表 4）、Qモデルの遷移確率 $q_{i j}$ は $t=-1 、 0$ 、 $1 の 3$ 時点のデータより推定し（表 5）、各々の遷 移確率を用いて、将来 $(t=2 、 3 、 4 、 \cdots)$ の土地利 用予測を行った（図 8）。

Qモデルによる各土地利用項目ごとの安定地点の 割合 $a_{j}$ の推定結果（表 6) から、安定地点の面積の 割合aがほぼ正確に推定されていることがわかる。 しかし、式(11)をみてもわかるように、 $p_{j}$ の值が大 きな（1に近い）場合には、式(11)の分母は非常に小 さな值となり、 $r_{j}$ の值がわずかに上下するだけでも $q_{j}$ の推定值は大きく変動してしまい、ひいては式(9)よ り求められる $a_{j}$ の值も大きく変動してしまう。つま り、 $p_{j j}$ の值が大きい場合には、 $a_{j}$ の推定值は不安定 になる危険性がある。このことは、 $p_{i j}$ の値の大きな 住宅用地（表 4）の $a_{j}$ の推定值 $a_{3}$ が、やや真の値か ら乘離していることにあらわれている。

さらに、図8に示した土地利用予測の結果をみる と、 $\mathrm{P}$ モデルでは $t=3$ 以後において山林農地と住宅 用地の構成比が逆転し、想定した真の推移にそぐわ ないが、Qモデルによれば、どの土地利用項目につ いても真の值に酷似した遷移を予測できることがわ かる。

図 8 には、Qモデルによる予測値の信頼性を確認 するため、予測伝播誤差に関する既往研究（青木ほ か、1994）にもとづき、予測値の信頼区間も同時に 示してある。従来の、いわば見せかけの遷移構造を もとに行った予測よりも、Qモデルによれば信頼性

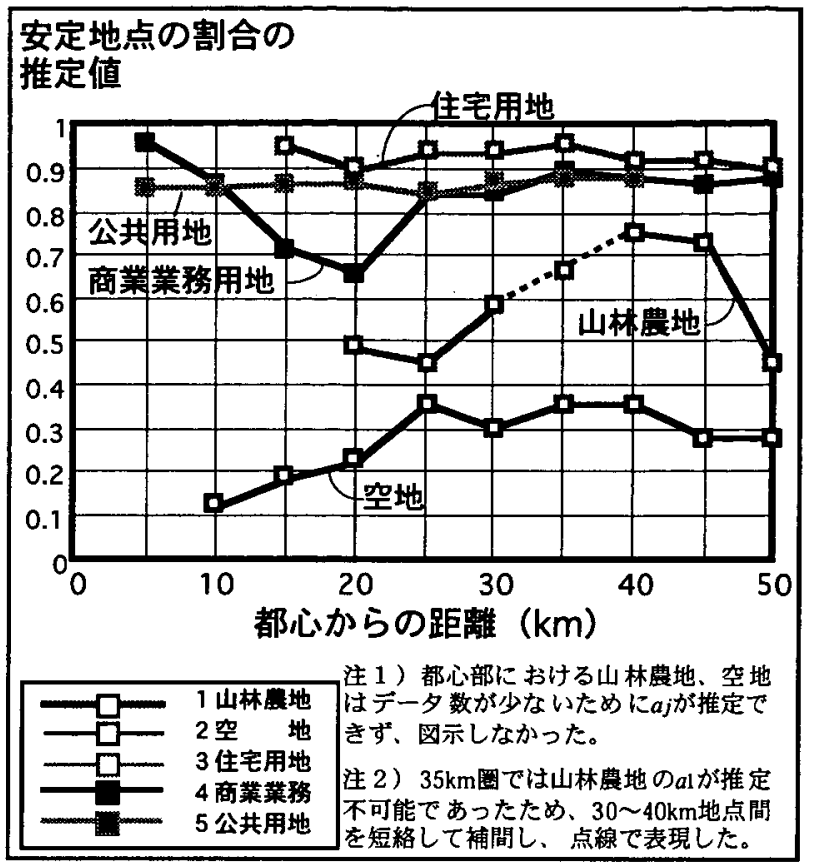

図 6 距離圈別の安定地点の面皘割合の推定結果

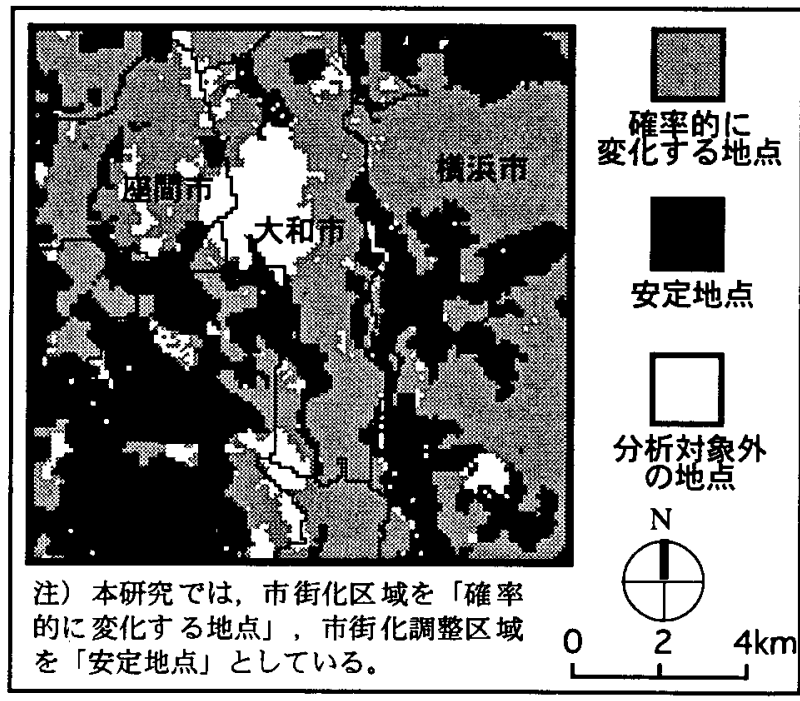

図 7 分析対象地域(B)

の高い予測が可能であることがわかる。

\section{6. まとめ}

本研究では、安定地点の存在を考慮しながら従来 の遷移確率モデル（Pモデル）に改良を加え、新し い遷移確率モデル（Qモデル）を構筑した。Qモデ ルを用いて土地利用における安定地点の割合を推定 した結果、各土地利用項目において多くの安定地点 が存在することが判明した。さらに、安定地点が存

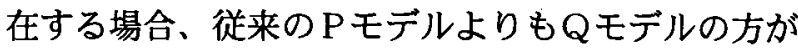


表 3 真の遷移確率行列 $q^{*} i j$

\begin{tabular}{|l|c|c|c|c|c|}
\hline$i$ & 1 山林農地 & 2 空地 & 3 住宅用地 & 4 商業業移 & 5 公共用地 \\
\hline 1 山林農地 & 0.662 & 0.073 & 0.017 & 0.015 & 0.003 \\
\hline 2 空地 & 0.097 & 0.466 & 0.018 & 0.034 & 0.004 \\
\hline 3 住宅用地 & 0.160 & 0.209 & 0.928 & 0.054 & 0.075 \\
\hline 4 商業業務 & 0.029 & 0.057 & 0.019 & 0.882 & 0.013 \\
\hline 5 公共用地 & 0.052 & 0.195 & 0.018 & 0.015 & 0.905 \\
\hline
\end{tabular}

表 4 対象地域全体で推定した遷移確率行列 $p_{i j}$

\begin{tabular}{|c|c|c|c|c|c|}
\hline$j$ & 1 山林農地 & 地 & 地 & 4 商業業務 & $5 \mu$ \\
\hline 【林㤟地 & 0.904 & 0041 & & & \\
\hline 空地 & & & & & \\
\hline 3 住宅 & & & & & \\
\hline 4 商業業務 & & & & & \\
\hline 公共用地 & 015 & $U_{i}$ & 0.016 & 0.01 & 0.9 \\
\hline
\end{tabular}

表 5 Qモデルを用いて推定した遷移確率行列 $q_{i j}$

\begin{tabular}{|c|c|c|c|c|c|}
\hline${ }_{i}>j$ & 1 山林農地 & 2 空地 & 3 住宅用地 & 4 商業業務 & 5 公共用地 \\
\hline 1 山林農地 & 0.661 & 0.074 & 0.016 & 0.015 & 0.003 \\
\hline 2 空地 & 0.097 & 0.467 & 0.017 & 0.036 & 0.004 \\
\hline 3 住宅用地 & 0.160 & 0.208 & 0.932 & 0.056 & 0.070 \\
\hline 4 商業菜務 & 0.029 & 0.057 & 0.017 & 0.878 & 0.011 \\
\hline 5 公共用地 & 0.053 & 0.194 & 0.018 & 0.015 & 0.912 \\
\hline
\end{tabular}

\section{表 6 安定地点の割合の推定値と真の值との比較}

\begin{tabular}{|c|c|c|c|c|c|}
\hline 項目 & 山林農地 & 空地 & 住宅用地 & 商業業務 & 公共用地 \\
\hline 真の値 & 0.715 & 0.442 & 0.120 & 0.141 & 0.265 \\
\hline 推定値 & 0.716 & 0.441 & 0.069 & 0.166 & 0.212 \\
\hline
\end{tabular}

正確な土地利用予測が可能である。したがって、土 地利用予測の際には安定地点の存在を考慮したQモ テルが有効である。

\section{謝辞}

本論文は、第 4 回地理情報システム学術研究発表 大会での発表（大佛・倍田、1995）をもとに加筆、 修正したものである。貴重なご意見、ご質問を頂い た方々に感謝の意を表します。

\section{参考文献}

青木義次 - 永井明子 - 大佛俊泰(1994)遷移確率行列 を用いた土地利用分析における誤差評価、「日 本建築学会計画系論文集」、第456号、171-177. 石坂公一(1992a)土地利用遷移行列の分析手法に関す る考察、「日本建築学会計画系論文報告集」、

第436号、59-69.

石坂公一(1992b) 首都圈における距離帯別の土地利用 変化動向、「日本建築学会計画系論文報告 集」、第442号、97-107.

大佛俊泰・倍田賢一(1995)マルコフ連鎖型土地利用 モデルの改良、「地理情報システム学会講演論 文集」、第4号、71-74.

金 俊栄・萩島 哲・大貝 彰・岩尾 襄 - 黒瀬重 幸(1991)土地利用遷移行列による都市の土地利 用用途転移の分析、「日本建築学会計画系論文 報告集」、第424号、69-78

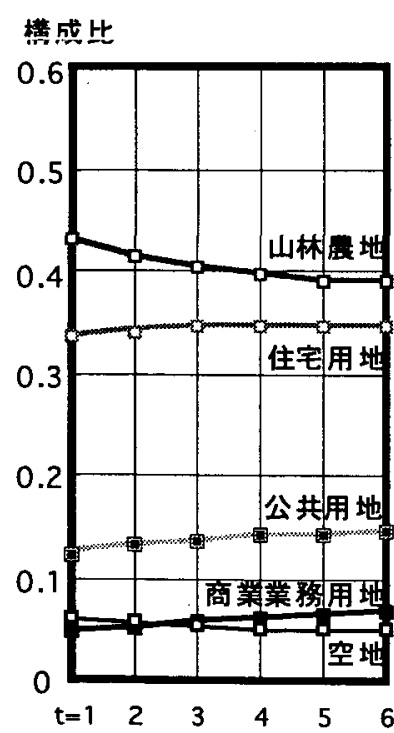

想定した真の遷移

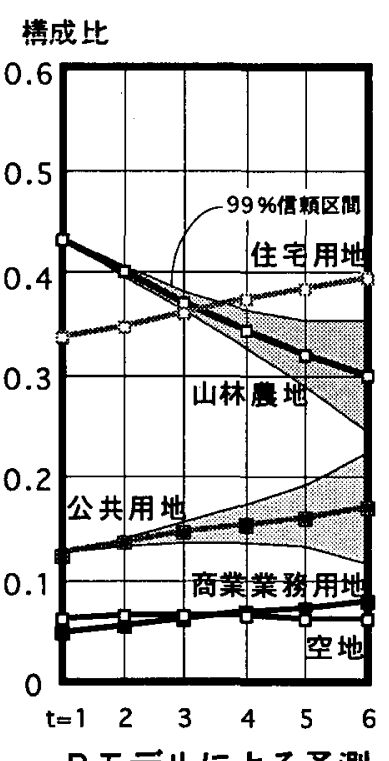

$P$ モデルによる予測
橝成比

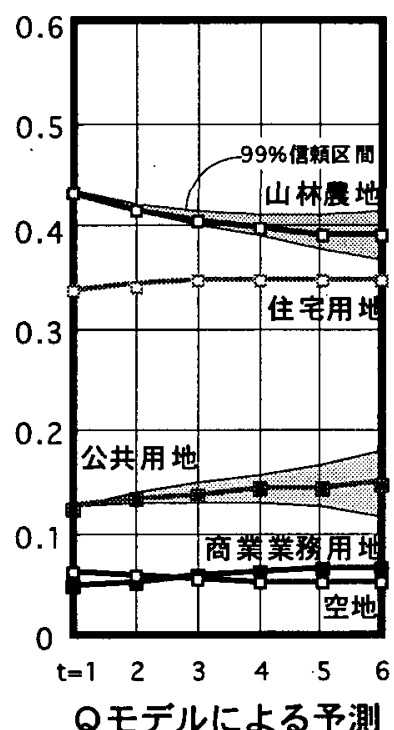

Qモデルによる予測

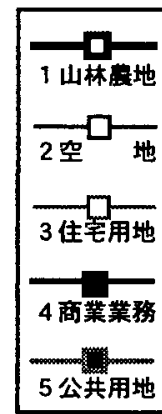

注） $99 \%$ 信頼 区間 は、「山林農地」 门公共用地」につけ てのみ表示した。

\section{図 8 PモデルとQモデルの予測比較}

